\title{
STRUKTUR KOMUNITAS DAN KONDISI KESEHATAN MANGROVE DI PULAU MIDDLEBURG-MIOSSU, PAPUA BARAT
}

\section{COMMUNITY STRUCTURE AND HEALTHINESS OF MANGROVE IN MIDDLEBURG-MIOSSU ISLAND, WEST PAPUA}

\author{
Doni Nurdiansah \& I Wayan Eka Dharmawan* \\ Pusat Penelitian Oseanografi (P2O), LIPI, Jakarta, 14430, Indonesia \\ *E-mail: iwayanekadharmawan@gmail.com
}

\begin{abstract}
Mangrove ecosystem plays important role in a small island's existence and provided ecosystem services. Its functionality highly depends on the size, community structure, and ecosystem quality. A field study on the mangrove quality in a small island was conducted on Middleburg-Miossu Island as a series of Nusa Manggala Expedition 2018. The study was aimed to analyze the community structure and mangrove health index (MHI) of mangroves on the island related to remote sensing-based vegetation indices. Mangrove area was divided into four zones (Z1-Z4). The study results showed that the outmost zone was dominated by Sonneratia alba (IVI 263.32\%), less than 50\% of canopy coverage, more than $20 \mathrm{~cm}$ of diameter, and a lower height. Meanwhile, the other three landward zones were dominated by type C. tagal with more than $80 \%$ of canopy coverage and higher sapling density. Based on the MHI value, mangrove in Middleburg-Miossu island was categorized into moderate ranging from 38.7 to $60.7 \%$. Based on AIC analysis, a combination of NBR, GCI, SIPI, and $A R V I$ vegetation indexes showed the highest regression coefficient, $R^{2}$-adjusted, for predicting $M H I$, which was 0.831. Interpolation of the predicted MHI value from the best model showed that $6.56 \mathrm{ha}$ mangroves at the research site or $40.74 \%$ were in the healthy condition.
\end{abstract}

Keywords: community structure, interpolation, mangrove, mangrove health index, zonation

\begin{abstract}
ABSTRAK
Ekosistem mangrove memiliki peranan penting bagi eksistensi dan penyediaan jasa ekosistem kepada masyarakat di pulau kecil. Fungsionalitas mangrove sangat tergantung dari ukuran, struktur komunitas dan kualitas ekosistem. Penelitian tentang penilaian kualitas struktur komunitas mangrove pulau kecil telah dilakukan di Pulau Middleburg-Miossu sebagai rangkaian dari Ekspedisi Nusa Manggala 2018. Penelitian ini bertujuan untuk menganalisis struktur komunitas dan indeks kesehatan mangrove (MHI) mangrove di pulau tersebut yang dihubungkan dengan indeks-indeks vegetasi berbasis pengindraan jauh. Lokasi penelitian dibagi menjadi empat zona (Z1-Z4) dan hasil penelitian menunjukkan bahwa zona terdepan didominasi oleh jenis Sonneratia alba (INP 263,32\%) dengan persentase tutupan kanopi $<50 \%$, ukuran diameter $>20 \mathrm{~cm}$ dan ketinggian tegakan yang lebih rendah. Sementara itu, tiga zona lainnya ke arah darat, didominasi oleh jenis Ceriops tagal dengan persentase tutupan kanopi $>80 \%$, serta kerapatan pancang yang cukup tinggi. Secara keseluruhan, kondisi kesehatan mangrove di lokasi penelitian termasuk dalam kategori sedang/cukup baik dengan rentang nilai MHI 38,7-60,7\%. Berdasarkan analisis AIC, kombinasi indeks vegetasi NBR, GCI, SIPI dan ARVI menunjukkan nilai koefisien regresi yang paling tinggi untuk memprediksi nilai MHI, yaitu 0,831. Interpolasi nilai MHI berdasarkan model regresi linier terbaik menunjukkan bahwa 6,56 ha mangrove di lokasi penelitian atau $40,74 \%$ termasuk dalam kategori sehat.
\end{abstract}

Kata kunci: interpolasi, mangrove indeks kesehatan mangrove (MHI), struktur komunitas, zonasi 


\section{PENDAHULUAN}

Indonesia merupakan negara kepulauan tropis yang memiliki luasan ekosistem mangrove terbesar di dunia. Penelitian Giri et al. (2011) menunjukkan bahwa sebanyak 22,6\% dari luasan mangrove global ditemukan di Indonesia. Program Satu Peta Kementerian Lingkungan Hidup dan Kehutanan menghasilkan data luasan mangrove Indonesia sebesar 3,36 juta ha (Rahadian et al., 2019). Walaupun luasan yang ditemukan saat ini telah tereduksi sekitar 140 ribu ha sejak tahun 2012 (Ilman et al., 2016). Degradasi mangrove Indonesia merupakan salah satu yang terbesar di dunia dan dipercaya berpengaruh signifikan pada perubahan iklim (Richards \& Friess, 2016; Atwood et al., 2017). Secara alamiah, sebaran mangrove di Indonesia yang sangat luas didukung oleh posisi geografis di wilayah tropis, panjang garis pantai terbesar kedua di dunia dan sebagian besar geomorfologi pesisir yang landai. Hal ini menyebabkan mangrove dapat tumbuh dengan baik bukan hanya di pulau yang dikategorikan berukuran besar, tapi juga ditemukan di pulau-pulau kecil (Nugroho et al., 2019; Dharmawan \& Pramudji, 2020; Insani et al., 2020; Kusmana et al., 2020).

Komunitas mangrove yang tumbuh pada pulau-pulau kecil memiliki peranan yang cukup signifikan secara ekologi, fisik, dan sosial ekonomi. Bersama dengan lamun dan terumbu karang, mangrove membentuk satu ekosistem pesisir yang lengkap untuk mendukung siklus hidup biota laut (Du et al., 2020). Biota yang bernilai ekonomis tinggi menjadi sumber pangan dan perdagangan diperoleh dari ekosistem mangrove (Benzeev et al., 2017; Aye et al., 2019; Seary et al., 2020). Nilai estetik ekosistem mangrove membuka peluang aktivitas pariwisata ekologi (Spalding \& Parrett, 2019). Isu perubahan iklim dan peningkatan muka air laut menjadikan mangrove sebagai pelindung untuk eksistensi pulau kecil (Wong et al., 2018). Mangrove mampu memberikan perlindungan terhadap dampak banjir rob dan abrasi pantai (Menéndez et al., 2020; Xiao et al., 2020). Ketersediaan air tawar bagi masyarakat pesisir juga didukung oleh keberadaan ekosistem mangrove yang memiliki kemampuan dalam mencegah intrusi air laut (Hilmi et al., 2017). Kayu mangrove juga dapat dimanfaatkan secara bijak untuk membuat struktur bangunan atau kapal (Tabalessy, 2014).

Fungsionalitas ekosistem mangrove berkaitan erat dengan ukuran, struktur tegakan dan kualitas komunitas mangrove. Lebar hutan dan struktur komunitas berpengaruh pada kemampuan mangrove dalam mereduksi gelombang (Bao, 2011, Horstman et al., 2014). Luasan yang lebih besar menyediakan jasa ekosistem dan nilai ekonomi yang lebih tinggi (Rizal et al., 2018). Ekosistem mangrove dengan jenis homogen memiliki jasa ekosistem karbon yang lebih rendah dibandingkan dengan mangrove campuran (Tinh et al., 2020). Namun, mangrove yang terdegradasi akan terancam kehilangan keanekaragaman biota dan jasa ekosistemnya (Carugati et al., 2018; Sippo et al., 2020). Oleh karena itu, penentuan kualitas komunitas mangrove sangat diperlukan untuk menganalisis jasa ekosistem mangrove.

Pengukuran kualitas kesehatan
mangrove dapat dilakukan menggunakan analisis parameter struktur komunitas, pengindraan jauh dan kombinasi dari keduanya. Penelitian Prasetya et al. (2017) menggunakan kerapatan pohon, indeks keanekaragaman, indeks keseragaman, dan jumlah spesies untuk menentukan nilai kesehatan mangrove. Namun, nilai ini akan tidak cukup stabil pada mangrove yang bersifat homogen seperti di pulau-pulau kecil. Sementara itu, penentuan kualitas mangrove secara spasial telah dipelajari dengan memanfaatkan data citra satelit (Razali et al., 2019; Chougule \& Sapkale, 2020). Penelitian Faridah-Hanum et al. (2019), memperkenalkan Mangrove Quality Index (MQI) yang mampu 
menggambarkan kualitas mangrove dari keterkaitan kondisi kesehatan parameter biotik, abiotik dan sosial ekonomi. Parameter yang cukup kompleks pada MQI menimbulkan permasalahan dalam kebutuhan sumber daya penelitian. Analisis Dharmawan et al. (2020a) terhadap dataset COREMAP CTI menghasilkan parameter struktur tegakan terseleksi untuk menyusun formula Mangrove Health Index (MHI) yang cukup sederhana sehingga mudah diterapkan. Nilai MHI menggambarkan kualitas komunitas mangrove yang merupakan subjek utama dalam ekosistem. Analisis pengindraan jauh menjadi peluang terkini untuk dimodelkan dengan nilai-nilai $\mathrm{MHI}$ sehingga memberikan gambaran kondisi kesehatan mangrove secara menyeluruh di satu lokasi penelitian. Oleh karena itu, analisis hubungan tersebut perlu diteliti lebih dalam untuk mendapatkan formulasi terbaik yang potensial untuk diterapkan secara lebih luas.

Penelitian ini bertujuan untuk menganalisis struktur komunitas dan indeks kesehatan mangrove (MHI) mangrove yang terdapat di sebuah pulau kecil. Pulau Middleburg-Miossu, Papua Barat dipilih sebagai lokasi studi kasus dalam penelitian ini karena merupakan salah satu pulau kecil terdepan Indonesia yang berbatasan langsung dengan Samudra Pasifik; adanya perlindungan mangrove melalui sasi oleh masyarakat untuk menjaga habitat biota laut tersebut, dan tidak berpenghuni karena masyarakat lebih memilih untuk tinggal di daratan utama Papua. Analisis spasial juga digunakan dalam penelitian ini untuk memberikan gambaran utuh tentang kondisi kesehatan komunitas mangrove.

\section{METODE PENELITIAN}

\subsection{Waktu dan Tempat}

Penelitian ini dilakukan di Pulau Middleburg-Miossu untuk mendukung Ekspedisi Nusa Manggala pada Desember
2018. Titik pengambilan data dibagi menjadi empat zona (Z1-Z4) berdasarkan nilai NDVI (Normalized Difference Vegetation Index). Gambaran awal tentang zonasi mangrove di lokasi penelitian mengacu pada ValderramaLanderos et al. (2018). Pada setiap zona dilakukan pembuatan plot penelitian untuk pengambilan data berdasarkan ketersediaan sumber daya (Gambar 1). Zona 4 memiliki luasan tertinggi dibandingkan dengan zona lainnya, yaitu 4,62 ha atau dengan proporsi $28,90 \%$. Sementara itu, luasan mangrove terendah pada zona 1 yang memiliki substrat keras (pasir dan pecahan karang) dengan luasan 3,69 ha atau 23,10\% dari total luasan mangrove. Zona 2 dan 3 memiliki luasan dan proporsi yang hampir mirip, yaitu 3,87 ha $(24,22 \%)$ dan 3,80 ha $(23,78 \%)$.

\subsection{Pengukuran Struktur Komunitas Mangrove}

Pengambilan data struktur komunitas mangrove dilakukan dengan memanfaatkan analisis citra satelit terutama dalam penentuan lokasi dan pengambilan kesimpulan struktur komunitas kawasan (Dharmawan et al., 2020a). Penempatan plot berukuran $10 \times 10 \mathrm{~m}\left(\mathrm{~A}=100 \mathrm{~m}^{2}\right)$ dalam pengambilan data dilakukan berdasarkan zonasi mangrove dengan metode stratified purposive sampling. Jumlah plot minimal pada tiap zona sebanyak tiga plot (Gambar 1). Lingkar batang tegakan mangrove atau keliling batang (KLL) diukur pada seluruh tegakan yang ditemukan pada kategori pohon $(\mathrm{KLL} \geq 16 \mathrm{~cm})$ dan pancang $(\mathrm{KLL}<16 \mathrm{~cm}$, minimal $5 \mathrm{~cm}$ ). Kategori semai yang memiliki tinggi $<1,5 \mathrm{~m}$ dan belum bercabang, dihitung dalam seluruh area plot. Seluruh tegakan pada setiap kategori diidentifikasi berdasarkan Tomlinson (2016). Pengukuran lingkar batang dilakukan untuk memperoleh data diameter (DBH), basal area (BA), frekuensi (F), kerapatan (K), dominansi jenis (D) dan Indeks Nilai Penting (INP). 


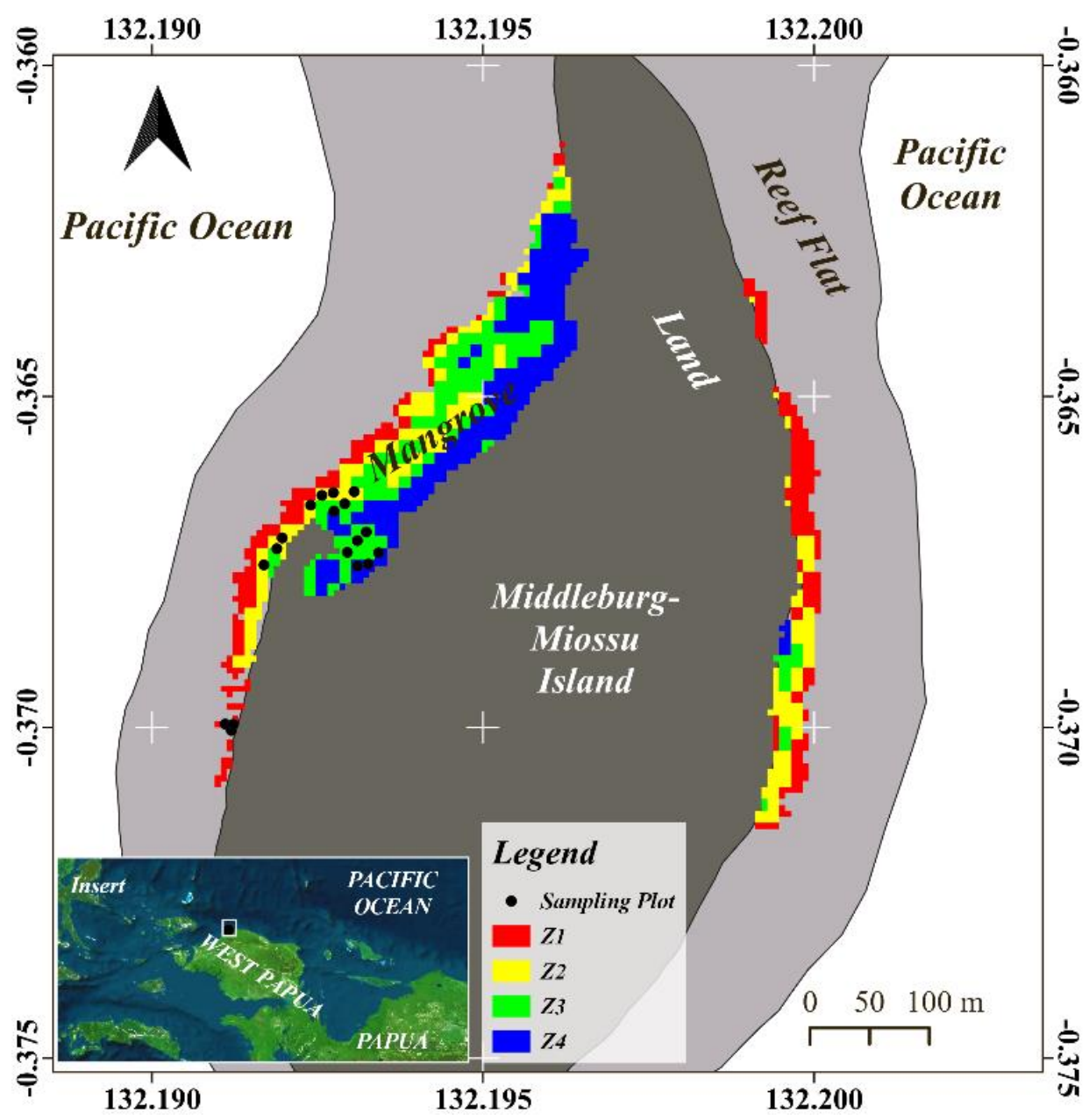

Gambar 1. Pengambilan sampel sebaran kuadrat pada setiap zona mangrove (Z1-Z4) di Pulau Middleburg-Miossu.

Figure 1. Sampling quadrates distribution on each mangrove zones (Z1-Z4) in MiddleburgMiossu island.

Tinggi komunitas mangrove $\left(\mathrm{H}_{\mathrm{t}}\right)$ diestimasi dengan melibatkan tiga data input yaitu, sudut puncak tegakan tertinggi $(\Theta)$ pada komunitas, tinggi mata pengamat dari tanah $\left(\mathrm{H}_{\mathrm{o}}\right)$ serta jarak pengukuran (d). Sudut tegakan diukur dengan menggunakan Protractor yang terpasang pada perangkat berbasis Android yang telah dikalibrasi sebelumnya. Penghitungan tinggi tegakan komunitas dilakukan mengikuti persamaan 1 .

$H t=H o+(\tan \theta \times d)$

Metode Hemispherical Photography digunakan untuk menentukan persentase tutupan kanopi komunitas mangrove. Sampel foto hemisphere diambil dengan menggunakan kamera ponsel pintar dengan resolusi 5 MP $\left(\mathrm{P}_{\text {total }}=5.038 .848\right.$ piksel $)$. Pengambilan foto dilakukan mengikuti persyaratan valid berdasarkan Dharmawan (2020). Sebanyak lima foto diambil pada setiap plot sehingga diperoleh 90 sampel secara keseluruhan. Foto dianalisis dengan menggunakan perangkat lunak imageJ untuk mendapatkan jumlah piksel pada foto yang merepresentasikan kanopi $\left(\mathrm{P}_{255}\right)$. Persentase tutupan kanopi komunitas mangrove (C) diperoleh dengan persamaan 2 .

$$
C=\frac{\text { P255 }}{\text { Ptotal }} \times 100 \%
$$




\subsection{Penghitungan Mangrove Health Index (MHI)}

Nilai MHI setiap plot diperoleh dari 3 komponen dari parameter struktur komunitas mangrove, yaitu: nilai skor dari persentase tutupan kanopi komunitas $\left(\mathrm{S}_{\mathrm{C}}\right)$, kerapatan pancang $\left(S_{n s p}\right)$ dan diameter pancang-pohon $\left(\mathrm{S}_{\mathrm{DBH}}\right)$ yang dihitung mengikuti persamaan 3-6 (Dharmawan et al., 2020a). Sementara itu, interpolasi MHI dilakukan dengan menggunakan koefisien regresi linier terbesar antara MHI dengan indeks vegetasi berbasis pengindraan jauh (Tabel 1). Citra satelit Sentinel 2 dengan kode L1C_T52MHE_A028485_20201205T01371 1 digunakan dalam analisis indeks vegetasi berbasis pengindraan jauh. Citra satelit dikoreksi secara atmosferik dan geometrik dengan menggunakan plug-in Semi-
Automatic Classification Plug-in (SCP) pada perangkat lunak QGIS (Purwanto \& Ardli, 2020).

$S c=0,25 \times C-13,06$

Snsp $=0,13 \times N s p+4,1$

$S d b h=0,45 \times D B H+1,42$

$M H I=\frac{(S c+5 n s p+S d b h)}{3} \times 10$

\subsection{Analisis Data}

Data persentase tutupan kanopi, kerapatan (pohon, pancang dan semai), diameter, tinggi dan basal area dianalisis secara deskriptif kuantitatif untuk mendapatkan nilai rata-rata dan standar

Tabel 1. Indeks vegetasi berdasarkan analisis penginderaan jauh yang digunakan dalam penelitian ini.

Table 1. Vegetation indices based on remote sensing analysis used in this study.

\begin{tabular}{|c|c|}
\hline Vegetation Indices Reference & Formula \\
\hline \multirow{2}{*}{ NDVI (Normalized Difference Vegetation Index) ${ }^{l}$} & NIR - Red \\
\hline & $\overline{N I R+R e d}$ \\
\hline \multirow{2}{*}{ MI (Mangrove Index $)^{l}$} & $\underline{N I R-S W I R}$ \\
\hline & $\overline{N I R} \times S W I R$ \\
\hline \multirow{2}{*}{ MVI (Mangrove Vegetation Index $)^{2}$} & $\underline{\| N I R-G r e e n \rrbracket}$ \\
\hline & $\overline{\mid S W I R-G r e e n]}$ \\
\hline SAVI (Soil Adjusted Vegetation Index $)^{l}$ & $\frac{N I R-R E D}{N I R+R E d+L} \times(1+L)$ \\
\hline \multirow{2}{*}{ NBR (Normalized Burn Ratio) ${ }^{1}$} & NIR-SWIR \\
\hline & $\overline{\text { NIR }+S W I R}$ \\
\hline GCI (Green Chlorophyll Index $)^{1}$ & $\frac{N I R}{\text { Green }}-1$ \\
\hline \multirow{2}{*}{ EVI (Enhanced Vegetation Index $)^{l}$} & NIR - Red \\
\hline & $G \times \overline{N I R+(C 1 \times R)-(C 2 \times \text { Blue })+L}$ \\
\hline \multirow{2}{*}{ SIPI (Structure Insensitive Pigment Index) ${ }^{l}$} & $\underline{\text { NIR }- \text { Blue }}$ \\
\hline & $\overline{\text { NIR-Red }}$ \\
\hline \multirow{2}{*}{ ARVI (Atmospherically Resistant Vegetation Index) ${ }^{l}$} & NIR $-2 \times$ Red + Blue \\
\hline & NIR +2xRed +Blue \\
\hline
\end{tabular}

Information: $N I R=$ Near Infrared, $S W I R=$ Short-wave Infrared, $L=1, G=2,5, C 1=6, C 2=$ 7.5. References: ${ }^{1}$ Dharmawan et al. (2020a); ${ }^{2}$ Baloloy et al. (2020). 
eror di setiap zona. Rata-rata data parameter tersebut dan indeks nilai penting (INP) setiap jenis pada seluruh area mangrove di Pulau Middleburg-Miossu dihitung dengan mempertimbangkan proporsi luasan mangrove pada setiap zona (Dharmawan et al., 2020a). Uji normalitas Shapiro-Wilk dilakukan untuk memperoleh sebaran data yang normal dan dilanjutkan dengan melakukan analisis parametrik selanjutnya. Analisis of variance (ANOVA) yang dilanjutkan dengan uji beda nyata Tukey pada setiap parameter dilakukan untuk memperoleh perbedaan nilai rata-rata antar zona. Analisis regresi linier setiap indeks vegetasi berbasis pengindraan jauh dengan nilai MHI setiap plot penelitian digunakan untuk memperoleh interpolasi nilai MHI terbaik pada citra satu band. Stepwise-Akaike Interference Criterion (AIC) juga dilakukan untuk mengidentifikasi kemungkinan pengaruh lebih dari satu indeks vegetasi terhadap nilai MHI. Nilai koefisien regresi $\left(R^{2}\right.$-adjusted) tertinggi digunakan untuk melakukan interpolasi sederhana sebaran MHI pada citra satu band yang disajikan dalam bentuk peta. Uji akurasi dilakukan dengan menggunakan Root Mean Square Error (RMSE) (Muhsoni et al., 2018). Luasan setiap kategori MHI berdasarkan hasil interpolasi model terbaik dihitung dengan menggunakan QGIS.

\section{HASIL DAN PEMBAHASAN}

\subsection{Struktur Komunitas Mangrove}

Secara keseluruhan, jenis Ceriops tagal mendominasi cukup tinggi di lokasi penelitian berdasarkan nilai INP sebesar $153,32 \%$ (Tabel 2). Sementara itu, jenis Sonneratia alba ditemukan dengan proporsi INP lebih rendah, yaitu $83,27 \%$. Nilai tersebut sangat dipengaruhi oleh dominansi jenis tersebut pada setiap zona. Jenis $C$. tagal mulai mendominasi pada zona 2 (Z2) dengan INP $125,47 \%$ dan kemudian semakin meningkat pada dua zona lainnya ke arah darat. Sedangkan, jenis $S$. alba sangat mendominasi pada zona terdepan yang memiliki substrat keras yang terdiri dari pasir putih dan rubble dengan INP 263,32\%. Dominansi jenis $S$. alba semakin berkurang ke arah daratan. Jenis B. gymnorrhiza dan $X$. granatum cenderung hanya ditemukan pada dua zona tengah (Z2 dan Z3). Jenis $X$. mollucensis tubuh cukup baik pada zona 3, sedangkan $R$. stylosa lebih banyak ditemukan pada zona 2.

Dominansi tinggi oleh jenis $C$. tagal pada zona 2 sampai 4 didukung oleh tipe substrat pasir berlumpur yang menjadi preferensi bagi jenis ini. Penelitian Pribadi et al. (2020) juga menemukan dominansi tinggi dari C. tagal dengan INP 263,62\% di Pulau Kanober, Kepulauan Ayau, Papua Barat.

Tabel 2. Species Important Value Index (INP) untuk setiap zona dan total luas di mangrove Middleburg-Miossu.

Table 2. Species Important Value Index (INP) for each zones and total area in MiddleburgMiossu's mangroves.

\begin{tabular}{lccccc}
\hline \multirow{2}{*}{ Mangrove Species } & \multicolumn{5}{c}{ Important Value Index/IVI (\%) each zone } \\
\cline { 2 - 6 } & Z1 & Z2 & Z3 & Z4 & Total \\
\hline Ceriops tagal & 0.00 & 125.47 & 176.30 & 280.26 & 153.32 \\
Bruguiera gymnorrhiza & 0.00 & 35.04 & 28.33 & 0.00 & 15.22 \\
Xylocarpus granatum & 0.00 & 13.23 & 22.69 & 0.00 & 8.60 \\
Xylocarpus molucensis & 0.00 & 6.73 & 22.68 & 19.74 & 12.73 \\
Rhizophora stylosa & 36.68 & 58.07 & 18.19 & 0.00 & 26.86 \\
Sonneratia alba & 263.32 & 61.47 & 31.81 & 0.00 & 83.27 \\
\hline
\end{tabular}


Penelitian Irwanto et al. (2020) menemukan jenis $C$. tagal zona tengah dan darat di Pulau Marsegu, Maluku pada komunitas mangrove yang didominasi oleh jenis B. gymnorrhiza. Sementara itu, jenis $S$. alba merupakan jenis yang cukup umum ditemukan mendominasi pada pulau-pulau yang bersubstrat pecahan karang. Dharmawan (2020) menemukan bahwa mangrove yang bersifat oseanik di pulau kecil Papua umumnya didominasi oleh $S$. alba. Pulau Owi dan Wundi di Biak bahkan didominasi penuh $(\mathrm{INP}=300 \%)$ oleh $S$. alba karena tipe substratnya yang keras, pasir dan pecahan karang.

Mangrove di Pulau MiddleburgMiossu dengan luasan 16,11 ha memiliki kondisi komunitas yang cukup baik. Berdasarkan Keputusan Menteri Lingkungan Hidup No 201, tahun 2004, persentase tutupan kanopi komunitas mangrove di Pulau Middleburg-Miossu tergolong padat $(\mathrm{C} \geq$ $75 \%$ ), dengan nilai rata-rata sebesar $75,82 \pm 2,60 \%$ (Tabel 3). Zona paling depan (Z1) yang didominasi oleh $S$. alba memiliki persentase tutupan kanopi komunitas mangrove paling rendah, yaitu $46,03 \pm 5,02 \%$ dan berbeda signifikan dengan zona penelitian lainnya (ANOVA: $\mathrm{p}<0,001$ ). Persentase tutupan kanopi mangrove pada tiga zona lainnya memiliki nilai yang tidak berbeda signifikan sekitar 84-85\% ( $p>0,05)$.
Penelitian Nurdiansah \& Dharmawan (2018) juga menemukan persentase tutupan kanopi yang lebih rendah pada komunitas mangrove yang didominasi penuh oleh $S$. alba $(61,02 \%)$ dibandingkan komunitas mangrove yang didominasi oleh Rhizophoraceae di perairan Tidore dan sekitarnya. Pada komunitas yang serupa di pulau - pulau karang di Kabupaten Biak diperoleh persentase tutupan kanopi sekitar 61,32\% (Dharmawan \& Pramudji, 2020). Sementara itu, pada komunitas mangrove Rhizophoraceae di wilayah mangrove alami Kabupaten Wondama, diperoleh persentase tutupan kanopi komunitas mangrove diatas $75 \%$ (Dharmawan \& Widyastuti, 2017). Penelitian di Kepulauan Ayau juga memperoleh persentase tutupan kanopi komunitas mangrove tergolong tinggi dengan rentang 76,57 - 86,49\% (Pribadi et al., 2020).

Persentase tutupan kanopi yang rendah pada zona terdepan (Z1) dipengaruhi oleh rendahnya kerapatan tegakan pohon yaitu sebesar $8 \pm 1$ tegakan $/ 100 \mathrm{~m}^{2}$. Selain itu juga karena dan ditemukannya tegakan pada kategori pancang (Table 3). Kerapatan pancang sangat berpengaruh terhadap persentase tutupan kanopi. Namun, komunitas $S$. alba memiliki tipe habitus unik yang cenderung berjarak satu sama lain antar pohon yang berukuran besar sehingga tidak

Tabel 3. Parameter komunitas mangrove: tutupan tajuk (\%), tinggi (m), kerapatan tegakan (tegakan / 100m2) dan diameter setinggi dada $(\mathrm{DBH}, \mathrm{cm})$ pada setiap zona.

Table 3. Mangrove community parameters: canopy coverage (\%), height (m), stands density $\left(\right.$ stand $\left./ 100 \mathrm{~m}^{2}\right)$ and diameter at breast-height $(\mathrm{DBH}, \mathrm{cm})$ on each zone.

\begin{tabular}{ccccccc}
\hline \multirow{2}{*}{ Sites } & Canopy & \multicolumn{3}{c}{ Density $\left(\right.$ stand/100m $\left.{ }^{2}\right)$} & \multirow{2}{*}{ Height $(\mathrm{m})$} & \multirow{2}{*}{ DBH $(\mathrm{cm})$} \\
\cline { 3 - 5 } & Coverage $(\%)$ & Tree & Sapling & Seedling & & \\
\hline$Z 1$ & $46.03 \pm 5.02^{\mathrm{a}}$ & $8 \pm 1^{\mathrm{a}}$ & $0 \pm 0^{\mathrm{a}}$ & $0 \pm 0^{\mathrm{a}}$ & $12.58 \pm 1.01^{\mathrm{a}}$ & $24.67 \pm 4.96^{\mathrm{a}}$ \\
$Z 2$ & $84.57 \pm 2.31^{\mathrm{b}}$ & $11 \pm 2^{\mathrm{a}}$ & $22 \pm 7^{\mathrm{b}}$ & $2 \pm 2^{\mathrm{b}}$ & $15.27 \pm 0.63^{\mathrm{b}}$ & $10.87 \pm 2.78^{\mathrm{b}}$ \\
$Z 3$ & $85.04 \pm 0.61^{\mathrm{b}}$ & $10 \pm 1^{\mathrm{a}}$ & $22 \pm 5^{\mathrm{b}}$ & $7 \pm 7^{\mathrm{b}}$ & $15.97 \pm 0.36^{\mathrm{b}}$ & $10.14 \pm 2.82^{\mathrm{b}}$ \\
$Z 4$ & $84.72 \pm 2.54^{\mathrm{b}}$ & $13 \pm 3^{\mathrm{a}}$ & $20 \pm 3^{\mathrm{b}}$ & $0 \pm 0^{\mathrm{b}}$ & $17.60 \pm 0.57^{\mathrm{b}}$ & $7.23 \pm 1.01^{\mathrm{b}}$ \\
Total & $75.82 \pm 2.60$ & $11 \pm 2$ & $16 \pm 4$ & $2 \pm 2$ & $15.49 \pm 0.63$ & $12.83 \pm 2.78$ \\
\hline
\end{tabular}

Information: Different superscripts following the values in the same parameter indicate significant differences among zones at a significance level of 5\% (ANOVA \& Tukey) (P $<0.05)$. The values are presented as mean \pm standard deviation. 
memungkinkan ditumbuhi pancang. Ratarata diameter pohon pada Z1 berukuran diatas $20 \mathrm{~cm}$ dan berbeda signifikan dengan dua stasiun lainnya. Nurdiansah \& Dharmawan (2018) dan Dharmawan \& Pramudji (2020) juga menemukan tren yang sama pada komunitas alami S. alba dengan kerapatan tegakan yang rendah namun memiliki ukuran yang cukup besar. Walaupun persentase tutupan kanopinya rendah, namun kelompok Sonneratia berkompetisi ruang dengan menghasilkan senyawa alelopati yang mampu menghambat pertumbuhan tegakan lainnya (Xin et al., 2013; Zhang et al., 2018).

Tegakan pancang pada komunitas mangrove yang didominasi oleh kelompok Rhizophoraceae pada kondisi alami ditemukan memiliki kerapatan yang cukup tinggi. Kerapatan pancang yang cukup rapat pada zona 2, 3 dan 4 didominasi oleh $C$. tagal (Tabel 3). Penelitian lainnya pada komunitas mangrove yang didominasi oleh kelompok Rhizophoraceae juga menghasilkan kerapatan pancang yang cukup tinggi, yaitu Wakatobi sebesar 23 tegakan $/ 100 \mathrm{~m}^{2}$ (Utama et al., 2019); Bintan sebanyak 32 tegakan/100m² (Rahmawati et al., 2019); Nias Utara 31 tegakan $/ 100 \mathrm{~m}^{2}$ (Giyanto et al., 2018); dan Anambas 22 tegakan $/ 100 \mathrm{~m}^{2}$ (Sari et al., 2018).

Pohon dan pancang yang padat dengan persentase tutupan yang tinggi pada zona $2-4$ berimplikasi pada pertumbuhan semai mangrove yang rendah. Jumlah semaian di lokasi penelitian tergolong cukup rendah dengan rentang $0-7$ tegakan $/ 100 \mathrm{~m}^{2}$ dan tidak berbeda signifikan antar lokasi penelitian ( $>0,05)$. (Tabel 3). Hasil penelitian ini jauh lebih rendah dibandingkan dengan mangrove di Nias Utara dengan rentang 7-107 tegakan $/ 100 \mathrm{~m}^{2}$ (Giyanto et al., 2018); Padaido-Biak dengan semaian 1- 100 tegakan $/ 100 \mathrm{~m}^{2}$ (Dharmawan et al., 2019); Anambas dengan kelimpahan 4-24 tegakan $/ 100 \mathrm{~m}^{2}$ (Sari et al., 2018); dan Wakatobi sebesar 0-82 tegakan $/ 100 \mathrm{~m}^{2}$ (Utama et al., 2019). Persentase tutupan kanopi memengaruhi celah dan intensitas cahaya yang merupakan salah satu faktor yang berpengaruh terhadap pertumbuhan semai (Peng et al., 2016). Kemampuan bertahan hidup semai menurun signifikan pada tutupan kanopi 60-90\% (Jiang et al., 2019).

Komunitas mangrove MiddleburgMiossu memiliki ketinggian rata-rata $15,49 \pm 0,64 \mathrm{~m}$. Zona 4 memiliki komunitas mangrove tertinggi dengan rata-rata sebesar $17,60 \pm 0,57 \mathrm{~m}$. Ketinggian komunitas mangrove pada zona 4 tidak berbeda signifikan dengan zona 2 dan 3 ( $p>0,05)$. Sementara itu, komunitas mangrove dengan ketinggian terendah ditemukan pada zona 1 dengan ukuran rata-rata 12,57 $\pm 1,01 \mathrm{~m}$ dan berbeda signifikan dengan ketinggian komunitas mangrove di zona lainnya. Walaupun demikian, ukuran diameter tegakan pada zona 1 jauh lebih besar dan berbeda signifikan dibandingkan zona lainnya dengan rata-rata $24,67 \pm 4,96 \mathrm{~cm}$ ( $>0,05)$. Nilai maksimal dari diameter tegakan mangrove yang ditemukan di Pulau Middleburg-Miossu adalah $124,73 \mathrm{~cm}$ pada jenis $S$. alba yang tumbuh pada zona 2 .

Komunitas mangrove di Pulau Middleburg-Miossu memiliki ketinggian dan diameter tegakan rata-rata cukup tinggi jika dibandingkan dengan penelitian sebelumnya yang juga dilakukan di pulau-pulau berkarakteristik substrat kapur dan pecahan karang. Monitoring yang dilakukan Utama et al. (2019) memperoleh ukuran tinggi dan diameter komunitas mangrove secara berturut-turut sebesar 9,27 $\pm 0,74 \mathrm{~m}$ dan $11,37 \pm 1,69 \mathrm{~cm}$ pada mangrove di Kabupaten Wakatobi. Hasil penelitian ini memiliki ukuran morfometrik tegakan mangrove yang jauh lebih besar dibandingkan penelitian di Kabupaten Nias Utara, yang ditemukan dengan ketinggian 5,37 $\pm 0,20 \mathrm{~m}$ dengan diameter 7,79 $\pm 0,37 \mathrm{~cm}$ (Giyanto et al., 2018). Penelitian Dharmawan et al. (2019) di pulau-pulau kecil di kawasan Taman Wisata Perairan Padaido menemukan ukuran tegakan mangrove yang lebih besar dengan 
ketinggian dan diameter tegakan berturutturut sebesar $16,64 \pm 1,74 \mathrm{~m}$ dan $20,54 \pm 3,82$ $\mathrm{cm}$.

\subsection{Indeks Kesehatan Mangrove (Mangrove Health Index, MHI)}

Secara keseluruhan kondisi kesehatan mangrove di Pulau Middleburg-Miossu tergolong dalam kategori yang cukup baik dengan rata-rata nilai MHI sekitar 60,7\% (Gambar 2). Indeks terendah ditemukan pada mangrove $\mathrm{Z1}$ dengan nilai $\mathrm{MHI}$ sebesar $38,7 \%$. Stasiun Z2 dan Z3 memiliki persentase nilai $\mathrm{MHI}$ diatas $66,7 \%$ yang menunjukkan kondisi kesehatan mangrove pada zona-zona tersebut sangat baik. Hasil penelitian ini mirip dengan hasil penelitian di Kabupaten Biak Numfor yang memperoleh nilai MHI sebesar $65 \%$ dengan rentang 39,3\%-76,8\% (Dharmawan et al., 2020a). Nilai MHI terendah pada zona 1 dipengaruhi oleh rendahnya nilai persentase tutupan kanopi komunitas serta tidak adanya regenerasi pada tingkat pancang. Mangrove pada zona 2 dan 3 memiliki nilai MHI lebih tinggi disebabkan parameter penyusun $\mathrm{MHI}$ ditemukan dengan nilai yang cukup tinggi, yaitu persentase tutupan kanopi, diameter dan kelimpahan pancang (Dharmawan et al., 2020b).

Hasil analisis regresi linier setiap indeks vegetasi berbasis pengindraan jauh dengan nilai MHI menunjukkan bahwa Mangrove Vegetation Index (MVI) memiliki signifikansi hubungan yang paling tinggi dibandingkan dengan indeks lainnya secara individual (Tabel 4). MVI merupakan salah satu pendekatan yang cepat dan akurat yang digunakan untuk mengidentifikasi ekosistem mangrove pada citra satelit. Indeks ini mempertimbangkan informasi kehijauan dan kelembababan dengan akurasi 92\% (Baloloy et al., 2020). Namun, hubungan yang lebih signifikan diperoleh dengan mengkombinasikan nilai indeks Normalized Burn Ratio (NBR), Green Chlorophyll Index (GCI), Structure Insensitive Pigment Index (SIPI) dan Atmospherically Resistant Vegetation Index (ARVI). Tiga indeks vegetasi pertama memiliki koefisien regresi yang lebih kecil dari 0,50 (Tabel 4). Indeks NBR digunakan untuk menganalisis area 2020). Indeks GCI (Green Chloropil Index) umumnya digunakan untuk mengestimasi

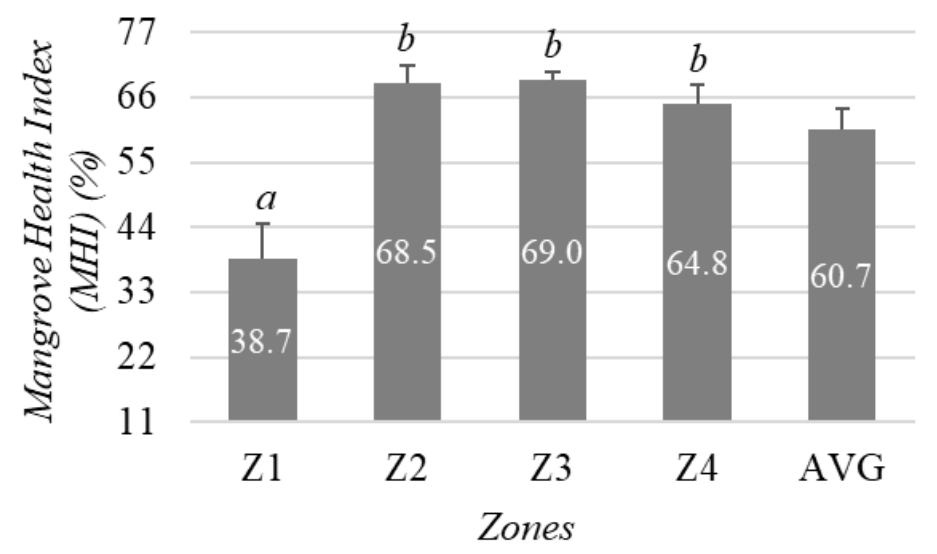

Gambar 2. Nilai Indeks Kesehatan Mangrove (MHI) (\%) tiap zona mangrove (Z1-Z4) dan total luas (AVG) di pulau Middleburg-Miossu. Nilai disajikan sebagai mean \pm standar deviasi. Huruf yang berbeda di atas batang menunjukkan perbedaan yang signifikan antar zona pada tingkat signifikansi $5 \%(\mathrm{P}<0,05)$.

Figure 2. Mangrove Health Index (MHI) value (\%) each mangrove zones (Z1-Z4) and total area $(A V G)$ in Middleburg-Miossu island. The values are presented as mean \pm standard deviation. Different letters above the bars show significant differences among zones at a significance level of $5 \%(P<0.05)$. 
Tabel 4. Model linier untuk memprediksi nilai MHI berdasarkan indeks vegetasi penginderaan jauh, koefisien regresi (disesuaikan R2), signifikansi (F), dan nilai uji akurasi (RMSE).

Table 4. Linear models for predicting MHI value based on remote sensing vegetation indices, regression coefficient $\left(R^{2}\right.$-adjusted), significance $(F)$, and accuracy-test value (RMSE).

\begin{tabular}{lcccc}
\hline $\begin{array}{l}\text { Vegetation } \\
\text { Indices }(X)\end{array}$ & Formula: MHI $(Y)=$ & $\begin{array}{c}R^{2}- \\
\text { adjusted }\end{array}$ & $F$ & $R M S E$ \\
\hline NDVI & $84.81 * \mathrm{NDVI}+16.709$ & 0.631 & $30.068 * * *$ & 7.31 \\
$M I$ & $-3.488^{*} \mathrm{MI}+97.967$ & 0.480 & $16.705 * *$ & 10.25 \\
$M V I$ & $28.367 * \mathrm{MVI}+75.135$ & 0.711 & $42.897 * * *$ & 6.46 \\
SAVI & $103.912 * \mathrm{SAVI}+31.845$ & 0.563 & $22.902 * * *$ & 7.95 \\
NBR & $209.780 * \mathrm{NBR}-79.158$ & 0.481 & $16.749 * *$ & 12.49 \\
$G C I$ & $2.677 * \mathrm{GCI}+45.22$ & 0.384 & $11.577 * *$ & 9.44 \\
$E V I$ & $7.85 * \mathrm{EVI}+41.965$ & 0.389 & $11.803 * *$ & 9.41 \\
SIPI & $-243.007 * \mathrm{SIPI}+322.104$ & 0.389 & $11.825 * *$ & 9.40 \\
$A R V I$ & $65.831 * \mathrm{ARVI}+25.264$ & 0.665 & $34.810 * * *$ & 6.96 \\
NBR,$G C I$, & $102.12 * \mathrm{NBR}-4.64 * \mathrm{GCI}$ & & \\
SIPI,ARVI & $+178.15 * \mathrm{SIPI}+159.53 * \mathrm{ARVI}-252.39$ & 0.831 & $21.8987 * * *$ & 4.46 \\
\hline
\end{tabular}

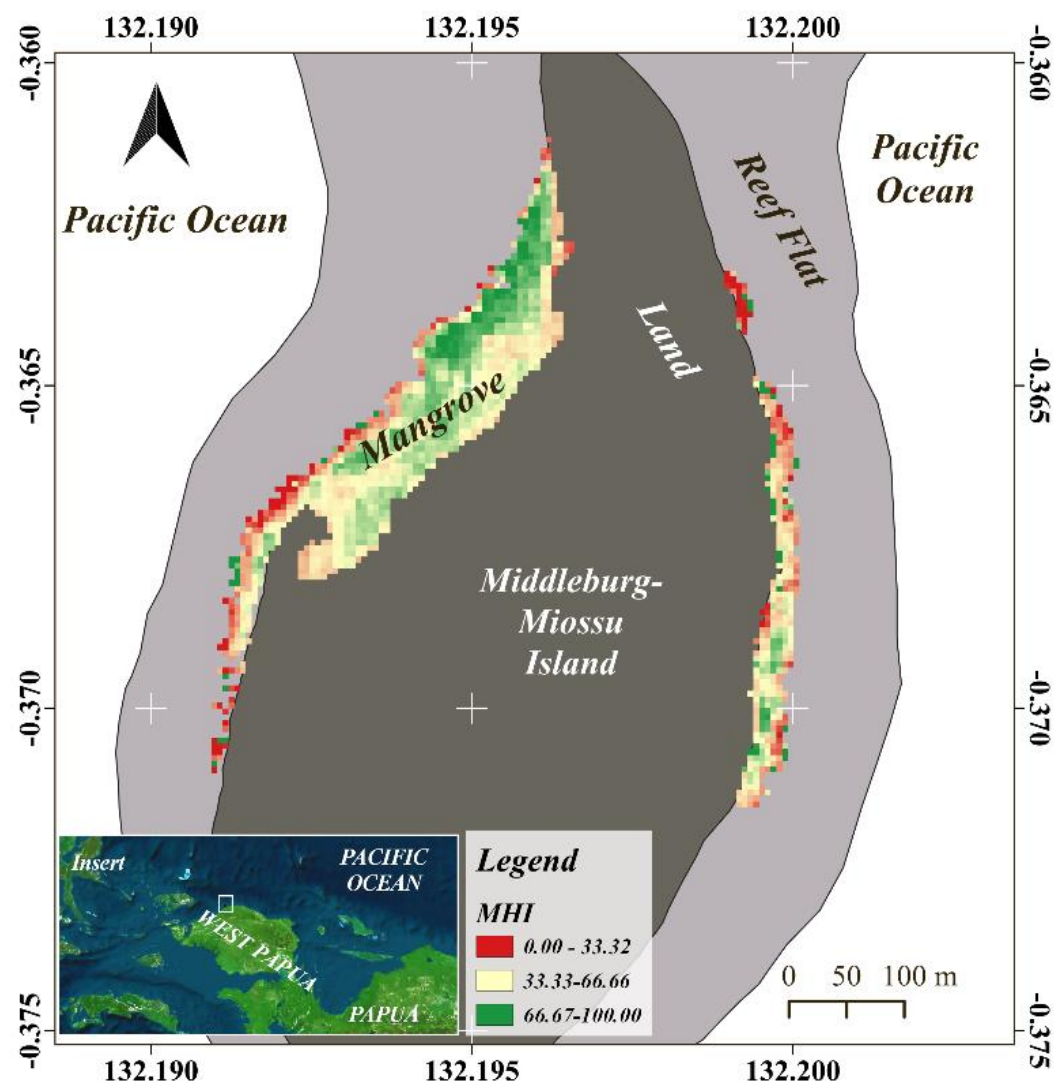

Gambar 3. Interpolasi nilai MHI mangrove Middleburg-Miossu berdasarkan model prediksi terbaik gabungan NBR, GCI, SIPI dan ARVI.

Figure 3. Interpolation of MHI value in Middleburg-Miossu's mangrove, based on the best predicting model combined by NBR, GCI, SIPI dan ARVI. 
Tabel 5. Luas (ha) dan proporsi (\%) untuk setiap kategori MHI pada ekosistem mangrove di Pulau Middleburg-Miossu.

Table 5. Area (ha) and proportion (\%) for each MHI category on the mangrove ecosystem in Middleburg-Miossu island.

\begin{tabular}{ccc}
\hline MHI Category & Area $($ ha $)$ & Proportion (\%) \\
\hline Poor & 0.57 & 3.53 \\
Moderate & 8.98 & 55.73 \\
Healthy & 6.56 & 40.74 \\
Total & 16.11 & 100.00 \\
\hline
\end{tabular}

kandungan klorofil daun pada spesies bervariasi untuk merefleksikan kondisi fisiologi dan kesehatan vegetasi (Wu et al., 2012). SIPI (Structure Insensitive Pigment Index) mempertimbangkan perbandingan karotenoid terhadap klorofil untuk dapat menggambarkan kesehatan mangrove (Chaube et al., 2019). Sementara itu. ARVI memiliki nilai koefisien regresi yang cukup tinggi dengan MHI. Penelitian Siddiq et al. (2020) menemukan korelasi ARVI yang cukup baik dengan parameter cadangan karbon mangrove di Teluk Benoa Bali.

Interpolasi dengan formulasi tersebut menunjukkan bahwa sebagian besar mangrove di Pulau Middleburg-Miossu memperlihatkan kondisi mangrove dalam kategori sedang $(55,73 \%)$ dan sebanyak $40,74 \%$ atau 6,56 ha tergolong dalam kondisi yang sangat baik. Hanya $3,53 \%$ area mangrove termasuk dalam kategori kesehatan yang buruk. (Gambar 3 dan Tabel 5). Nilai interpolasi ini cukup baik digunakan karena hasil uji akurasi diperoleh nilai RMSE sebesar 4,46\% atau kurang dari 5\% (Tabel 4). Semakin rendah nilai RMSE menunjukkan formula yang digunakan semakin baik untuk memprediksi nilai sebenarnya (Siddiq et al., 2020).

\section{KESIMPULAN}

Pulau Middleburg-Miossu memiliki komunitas mangrove yang didominasi oleh C. tagal pada zona-zona darat dengan persentase tutupan kanopi dan kerapatan pancang yang tinggi. Sementara itu, pada zona terluar ditemukan $S$. alba yang tumbuh dengan baik dengan ukuran diameter tegakan yang cukup besar dan tinggi tegakan yang lebih rendah dibandingkan dengan zona lainnya. Komunitas mangrove secara keseluruhan menunjukkan kondisi kesehatan yang cukup baik atau kategori sedang berdasarkan nilai MHI. Penerapan kombinasi analisis pengindraan jauh dengan analisis struktur komunitas mangrove dan MHI mampu memberikan gambaran yang lebih utuh tentang kesehatan komunitas mangrove di Pulau Middleburg-Miossu. Hanya kurang dari 5\% mangrove di Pulau MiddleburgMiossu yang memiliki kondisi kesehatan komunitas yang kurang baik.

\section{UCAPAN TERIMA KASIH}

Terima kasih kami ucapkan kepada PMO COREMAP CTI, LIPI serta segenap staf peneliti dan non peneliti dalam Ekspedisi Nusa Manggala tahun 2018 yang didanai oleh World Bank. Terima kasih juga kepada Kepala Pusat Penelitian Oseanografi yang telah memberikan dukungan dalam pelaksanaan penelitian.

\section{DAFTAR PUSTAKA}

Atwood, T.B., R.M. Connolly, H. Almahasheer, P.E. Carnell, C.M. Duarte, C.J.E. Lewis, X. Irigoien, J.J. Kelleway, P.S. Lavery, P.I. Macreadie, \& O. Serrano. 2017. Global patterns in mangrove soil 
carbon stocks and losses. Nature Climate Change, 7(7): 523-528. https://doi.org/10.1038/nclimate3326

Aye, W.N., Y. Wen, K. Marin, S. Thapa, \& A.W. Tun. 2019. Contribution of mangrove forest to the livelihood of local communities in Ayeyarwaddy region, Myanmar. Forests, 10(5): 414-426. https://doi.org/10.3390/f10050414

Baloloy, A.B., A.C. Blanco, R.R.C.S. Ana, \& K. Nadaoka. 2020. Development and application of a new mangrove vegetation index (MVI) for rapid and accurate mangrove mapping. ISPRS J. of Photogrammetry and Remote Sensing, 166: 95-117. https://doi.org/10.1016/j.isprsjprs.202 0.06 .001

Bao, T.Q. 2011. Effect of mangrove forest structures on wave attenuation in coastal Vietnam. Oceanologia, 53(3): 807-818. https://doi.org/10.5697/oc.53-3.807

Benzeev, R., N. Hutchinson, \& D.A. Friess. 2017. Quantifying fisheries ecosystem services of mangroves and tropical artificial urban shorelines. Hydrobiologia, 803(1): 225-237. https://doi.org/10.1007/s10750-0173299-8

Carugati, L., B. Gatto, E. Rastelli, M.L. Martire, C. Coral, S. Greco, \& R. Danovaro. 2018. Impact of mangrove forests degradation on biodiversity and ecosystem functioning. Scientific reports, 8(1): 1-11. https://doi.org/10.1038/s41598-01831683-0

Chaube, N.R., N. Lele, A. Misra, T.V.R. Murthy, S. Manna, S. Hazra, M. Panda, \& R.N. Samal. 2019. Mangrove species discrimination and health assessment using AVIRIS-NG hyperspectral data. Current Sciences, 116: 1136-1142. https://doi.org/10.18520/cs/v116/i7/1 136-1142
Chougule, V.A. \& J.B. Sapkale. 2020. Detecting changes and health status of mangrove forest in Achara estuary, Maraharashtra using remote sensing and GIS. Sustainability, Agri, Food and Environmental Research, 8(3): 212-221. https://doi.org/10.7770/safer-V0N0art2093

Dharmawan, I.W.E. \& A. Widyastuti. 2017. Pristine mangrove community in Wondama gulf, West Papua, Indonesia. Marine Research in Indonesia, 42(2): 73-82. https://doi.org/10.14203/mri.v42i2.17 5

Dharmawan, I.W.E., R.S. Utama, Giyanto, L.P. Aji, P.C. Makatipu \& A. Irawan. 2019. Monitoring kondisi kesehatan terumbu karang dan ekosistem pesisir terkait di TWP. Padaido, BiakNumfor. COREMAP-CTI, LIPI. Jakarta. 152 hlm.

Dharmawan, I.W.E. \& Pramudji. 2020. Mangrove community structure in Papuan Small Islands, Case Study in Biak Regency. Proceeding The IOP Conference Series: Earth and Environmental Science, Purwokerto, Indonesia, 21 - 23 August 2019. 1-8 pp. https://doi.org/doi:10.1088/17551315/550/1/012002

Dharmawan, I.W.E., Suyarso, Y.I. Ulumuddin, B. Prayudha \& Pramudji. 2020a. Manual for mangrove community structure monitoring and research in Indonesia. NAS Media Pustaka. Makassar. $150 \mathrm{p}$.

Dharmawan, I.W.E., T.A. Hadi, U.Y. Arbi, P.C. Makatipu, S. Rahmawati, A. Budiyanto, A.B. Sitepu, B. Usman, P. Halang, Y. Kapitaraw, A. Sulaksmana, F.C.E. Dan \& B. Otoluwa. 2020b. Monitoring kesehatan terumbu karang dan ekosistem terkait di Kabupaten BiakNumfor. COREMAP CTI, LIPI. Jakarta. $231 \mathrm{p}$. 
Du, J., M. Xie, Y. Wang, Z. Chen, W. Liu, J. Liao, \& B. Chen. 2020. Connectivity of fish assemblages along the mangrove-seagrass-coral reef continuum in Wenchang, China. Acta Oceanologica Sinica, 39(8): 43-52. https://doi.org/10.1007/s13131-0191490-7

Faridah-Hanum, I., F.M. Yusoff, A. Fitrianto, N.A. Ainuddin, S. Gandaseca, S. Zaiton, K. Norizah, S. Nurhidayu, M.K. Roslan, K.R. Hakeem, \& I. Shamsuddin. 2019. Development of a comprehensive mangrove quality index (MQI) in Matang Mangrove: Assessing mangrove ecosystem health. Ecological Indicators, 102: 103-117. https://doi.org/10.1016/j.ecolind.2019 .02 .030

Giri, C., E. Ochieng, L.L. Tieszen, Z. Zhu, A. Singh, T. Loveland, J Masek, \& N. Duke. 2011. Status and distribution of mangrove forests of the world using earth observation satellite data. Global Ecology and Biogeography, 20(1): 154-159. https://doi.org/10.1111/j.14668238.2010.00584.x

Giyanto, Mudjiono, F.D. Hukom, J. Picasouw, S. Unyang, R. Haryanto, Djuwariah, L. Tanda, A.B. Sitepu, A. Sidiq, Samsuardi, M.Y. Amrullah, Y. Zai, J. Gea, \& A.P. Siregar. 2018. Monitoring kesehatan terumbu karang dan ekosistem terkait di Kabupaten Nias Utara. COREMAP-CTI, LIPI. Jakarta. 120 p.

Hilmi, E., C. Kusmana, E. Suhendang, \& I. Iskandar. 2017. Correlation analysis between seawater intrusion and mangrove greenbelt. Indonesian J. of Forestry Research, 4(2): 151-168. https://doi.org/10.20886/ijfr.2017.4.2. 151-168

Horstman, E.M., C.M. Dohmen-Janssen, P.M.F. Narra, N.J.F. Van den Berg, M. Siemerink, \& S.J. Hulscher. 2014.
Wave attenuation in mangroves: A quantitative approach to field observations. Coastal Engineering, 94: 47-62.

https://doi.org/10.1016/j.coastaleng.2 014.08.005

Ilman, M., P. Dargusch, \& P. Dart. 2016. A historical analysis of the drivers of loss and degradation of Indonesia's mangroves. Land use policy, 54: 448459.

https://doi.org/10.1016/j.landusepol.2 016.03.010

Insani, W.O.N., W. Widayati, \& S. Sawaludin. 2020. Analisis Degradasi hutan mangrove di Kecamatan Kaledupa Kabupaten Wakatobi. JAGAT, 4(1): 15-24. https://doi.org/10.5281/zenodo.38712 58

Irwanto, I., S.A. Paembonan, N.P. Oka, \& R.I. Maulany. 2020. Growth characteristics of the mangrove forest at the raised coral island of Marsegu, West Seram, Maluku. International J. of Innovative Science and Research Technology, 5(10): 211-219. https://ijisrt.com/assets/upload/files/IJ ISRT20OCT247.pdf

Jiang, Z., W. Guan, Y. Xiong, M. Li, Y. Chen, \& B. Liao. 2019. Interactive effects of intertidal elevation and light level on early growth of five mangrove species under Sonneratia apetala Buch. Hamplantation canopy: Turning monocultures to mixed forests. Forests, 10(2): 83-97. https://doi.org/10.3390/f10020083

Kusmana, C., F.G. Dwiyanti, \& Z. Malik. 2020. Comparison of several methods of stands inventory prior to logging towards the yield volume of mangrove forest in Bintuni Bay, West Papua Province, Indonesia. Biodiversitas J. of Biological Diversity, 21(4): 14381447. 
https://doi.org/10.13057/biodiv/d2104 23

Menéndez, P., I.J. Losada, S. Torres-Ortega, S. Narayan, \& M.W. Beck. 2020. The global flood protection benefits of mangroves. Scientific reports, 10(1): $1-11$. https://doi.org/10.1038/s41598-02061136-6

Muhsoni, F.F., A.B. Sambah, M. Mahmudi, \& D.G.R. Wiadnya. 2018. Comparison of different vegetation indices for assessing mangrove density using sentinel-2 imagery. Int. J. Geomate, 14: 42-51. https://doi.org/10.21660/2018.45.717 7

Nugroho, T.S., A. Fahrudin, F. Yulianda, \& D.G. Bengen. 2019. Structure and composition of riverine and fringe mangroves at Muara Kubu protected areas, West Kalimantan, Indonesia. Aquaculture, Aquarium, Conservation \& Legislation, 12(1): 378-393.

https://www.bioflux.com.ro/docs/201 9.378-393.pdf

Nurdiansah, D. \& I.W.E Dharmawan. 2018. Komunitas mangrove di wilayah pesisir Pulau Tidore dan sekitarnya. Oseanologi dan Limnologi di Indonesia, 3(1): 1-9. https://doi.org/10.14203/oldi.2018.v3i 1.63

Peng, Y., J. Diao, M. Zheng, D. Guan, R. Zhang, G. Chen, \& S.Y. Lee. 2016. Early growth adaptability of four mangrove species under the canopy of an introduced mangrove plantation: Implications for restoration. Forest Ecology and Management, 373: 179188.

https://doi.org/10.1016/j.foreco.2016. 04.044

Prasetya, J.D. \& F. Purwanti. 2017. Mangrove health index as part of sustainable management in mangrove ecosystem at Karimunjawa National
Marine Park Indonesia. Advanced Science Letters, 23(4): 3277-3282. https://doi.org/10.1166/asl.2017.9155

Pribadi, R., I.W.E. Dharmawan, \& A.K. Bahari. 2020. Penilaian kondisi kesehatan ekosistem mangrove di Ayau dan Ayau Kepulauan, Kabupaten Raja Ampat. Majalah Ilmiah Biologi Biosfera, 37(2): 106111.

https://doi.org/10.20884/1.mib.2020.3 7.2.1206

Purwanto, A.D. \& E.R. Ardli. 2020. Development of a simple method for detecting mangrove using free open source software. J. Segara, 16(2): 7182.

https://doi.org/10.15578/segara.v16i2. 7512

Que, V.K.S., S.Y.J. Prasetyo, \& C. Fibriani. 2019. Analisis perbedaan indeks vegetasi normalized difference vegetation index (NDVI) dan normalized burn ratio (NBR) Kabupaten Pelalawan Menggunakan Citra Satelit Landsat 8. Indonesian J. of Computing and Modeling, 2(1): 17.

https://ejournal.uksw.edu/icm/article/ view/2534/1177

Rahadian, A., L.B. Prasetyo, Y. Setiawan, \& K. Wikantika. 2019. A historical review of data and information of Indonesian mangroves area. Media Konservasi, 24(2): 163-178.

https://doi.org/10.29244/medkon.24.2 .163-178

Rahmawati, S., D. Kurniawan, R.D. Putra, I.B. Vimono, I.P. Putra, I.W.E. Dharmawan, B. Prayudha, U.Y. Arbi, U.E. Hernawan, A. Budiyanto, A. Rasyidin, M. Sinaga, \& S.H.M. Nainggolan. 2019. Pemantauan kesehatan terumbu karang dan ekosistem terkait di Kabupaten Bintan. COREMAP CTI-LIPI, Jakarta. 117 hlm. 
Rahmi, K.I.N. \& N. Febrianti. 2020. Pemanfaatan data sentinel-2 untuk analisis indeks area terbakar (burned area). J. Pengindraan Jauh Indonesia, 2(1): 1-6.

https://jurnal.mapin.or.id/index.php/jp ji/article/view/21/15

Razali, S.M., A.A. Nuruddin, \& M. Lion. 2019. Mangrove vegetation health assessment based on remote sensing indices for Tanjung Piai, Malay Peninsular. J. of Landscape Ecology, 12(2): 26-40.

https://doi.org/10.2478/jlecol-20190008

Richards, D.R. \& D.A. Friess. 2016. Rates and drivers of mangrove deforestation in Southeast Asia, 2000-2012. Proceedings of the National Academy of Sciences, 113(2): 344-349.

https://doi.org/10.1073/pnas.1510272 113

Rizal, A., A. Sahidin, \& H. Herawati. 2018. Economic value estimation of mangrove ecosystems in Indonesia. Biodiversity International J., 2(1): 98-100.

https://doi.org/10.15406/bij.2018.02.0 0051

Sari, NWP., M. Abrar, R.M. Siringoringo, Nurhasim, R.D. Putra, M. Sinaga, Jumsurizal, Irawan, F. Lestari, I. Pangestyansyah, A. Rasyidin, R. Sutiyadi, O.R. Sianturi, B.Perisha. 2018. Monitoring Kesehatan Terumbu Karang dan Ekosistem Terkait di Kawasan Konservasi Perairan Nasional, Taman Wisata Perairan, Kepulauan Anambas dan Laut Sekitarnya. COREMAP-CTI, LIPI. Jakarta. 103 p.

Seary, R., T. Spencer, M. Bithell, \& C. McOwen. 2020. Measuring mangrove-fishery benefits in the Peam Krasaop Fishing Community, Cambodia. Estuarine, Coastal and Shelf Science, 106918: 1-10. https://doi.org/10.1016/j.ecss.2020.10 6918

Siddiq, A., M. Dimyati, \& A. Damayanti. 2020. Analysis of carbon stock distribution of mangrove forests in the coastal city of Benoa, Bali with combination vegetation index, and statistics approach. International J. on Advanced Science, Engineering and Information Technology, 10(6): 23862393.

https://doi.org/10.18517/ijaseit.10.6.1 2991

Sippo, J.Z., C.J. Sanders, I.R. Santos, L.C. Jeffrey, M. Call, Y. Harada, K. Maguire, D. Brown, S.R. Conrad, \& D.T. Maher. 2020. Coastal carbon cycle changes following mangrove loss. Limnology and Oceanography, 65(11): 2642-2656.

https://doi.org/10.1002/lno.11476

Spalding, M. \& C.L. Parrett. 2019. Global patterns in mangrove recreation and tourism. Marine Policy, 110: 103540103547.

https://doi.org/10.1016/j.marpol.2019. 103540

Tabalessy, R. 2014. Economic value analysis of mangrove forest ecosystems in Sorong, West Papua Province. Aquatic Science \& Management, 2: $39-43$.

https://doi.org/10.35800/jasm.0.0.201 4.7305

Tinh, H.P., N.T.H. Hanh, V.V. Thanh, M.S. Tuan, P.V. Quang, S.P. Sharma, \& R.A. MacKenzie. 2020. A comparison of soil carbon stocks of intact and restored mangrove forests in northern Vietnam. Forests, 11(6): 660-669.

https://doi.org/10.3390/f11060660

Tomlinson, P.B., 2016. The Botany of Mangroves, Second Edition. Cambridge University Press, UK, 432 p.

Utama, R.S., H.A.W. Cappenberg, D. Anggraeni, I.N. Edrus, P. Makatipu, 
A. Irawan, I.W.E. Dharmawan, A. Budiyanto, A.R. Dzumalex, \& A. Salatalohi. 2019. Kondisi kesehatan terumbu karang dan ekosistem terkait di Kabupaten Wakatobi, Sulawesi Tenggara. COREMAP CTI-LIPI. Jakarta. $102 \mathrm{hlm}$.

Valderrama-Landeros, L., F. Flores-deSantiago, J.M. Kovacs, \& F. FloresVerdugo. 2018. An assessment of commonly employed satellite-based remote sensors for mapping mangrove species in Mexico using an NDVI-based classification scheme. Environmental monitoring and assessment, 190(1): 1-13. https://doi.org/10.1007/s10661-0176399-z

Wong, P.P. 2018. Coastal protection measures-case of Small Island Developing States to address sealevel rise. Asian J. of Environment \& Ecology, 6(3): 1-14. https://doi.org/10.9734/AJEE/2018/41 019

Wu, C., Z. Niu, \& S. Gao. 2012. The potential of the satellite-derived green chlorophyll index for estimating midday light use efficiency in maize, coniferous forest and grassland. Ecological Indicators, 14(1): 66-73. https://doi.org/10.1016/j.ecolind.2011 .08 .018
Xiao, H., F. Su, D. Fu, Q. Wang, \& C. Huang. 2020. Coastal mangrove response to marine erosion: Evaluating the impacts of spatial distribution and vegetation growth in Bangkok Bay from 1987 to 2017. Remote Sensing, 12(2): 220-235. https://doi.org/10.3390/rs12020220

Xin, K., Q. Zhou, S.K. Arndt, \& X. Yang. Invasive capacity of the mangrove Sonneratia apetala in Hainan Island, China. J. of Tropical Forest Science, 25(1): 70-78.

https://www.frim.gov.my/v1/JTFSOn line/jtfs/v25n1/70-78.pdf

Zhang, Y., F.P. Liang, Y.Y.W. Li, J.W. Zhang, S.J. Zhang, H. Bai, Q. Liu, C.Y.R. Zhong, \& L. Li. 2018. Allelopathic effects of leachates from two alien mangrove species, Sonneratia apetala and Laguncularia racemosa on seed germination, seedling growth and antioxidative activity of a native mangrove species Sonneratia caseolaris. Allelopathy J., 44(1): 119-130. https://doi.org/10.26651/allelo.j/201844-1-1158

Received : 10 February 2021

Reviewed: 15 March 2021

Accepted : 18 April 2021 